以上の実験結果から，つぎのように結論できると思う。マンガ ン（I）はアルカリ性クエン酸塩溶液中でただちにマンガン(I)-ク エン酸单核錯体を生成する。この錯体は電極活性でマンガン（II） への酸化波およびマンガン $(0)$ への還元波を与える。時間の経過
とともにこの単核錯体はマンガン 4 個をもつ電㥛不活性な多核鍇

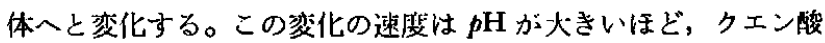
浱度が小さいほど大きい。

\title{
隍イオン交换法によるアンチモン，スズ，モリブデンの分離
}

(昭和 40 年 8 月 26 日受理)

$$
\text { 河 淵 計 明*1 }
$$

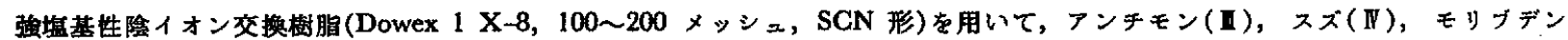

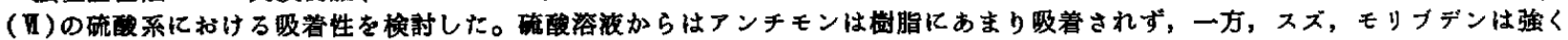
吸着される。樹䏣に捕捉されたスズとモリブデンは $0.5 \mathrm{~mol} / l$ 熄化ナトリウム $-0.5 \mathrm{~mol} / l$ 水酸化ナトリウム溶液で容易に溶離で きるが，画者の分布保数にわずかに差異のあるととがわかった。てれらの事実に基づき， $3 \mathrm{~N}$ 㙁酸溶液から金風イオンを $0.5 \mathrm{~cm}^{2}$ $\times 12 \mathrm{~cm}$ のカラムに眀着させ，アンチモンは $1 \mathrm{~N}$ 硫酸で, スズとモリブデンは $0.5 \mathrm{~mol} / l$ 塩化ナトリウム $-0.5 \mathrm{~mol} / l$ 水酸化ナ トリウム溶激でそれぞれ溶㲝し，てれらの金属元素を分噰した。

\section{1 喜}

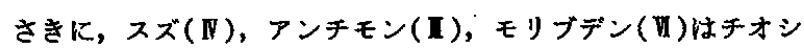
アン酸形陰イオン交換樹脂に強く捕捉されるが，アンチモンは硫 酸で，スズとモリブデンは程化ナトリウムー水酸化ナトリウム溶 液で溶離できることを報告12)した。これらの金属元素の相互分 離は分析化学的に重要であり，なかであスズをジオール法3),

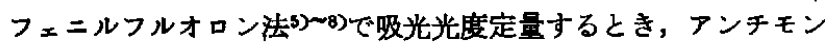
やモリブデンが共存するといちじるしく妨害するため，定量にさ き立ちこれらの妨害元素を除去するか，スズを分蜼する必要があ る。また，スズの放射化学りにおいても，スズからヒ素,テルル， アンチモン，モリブデンの除去はもっとも困奞な操作とされてお り，好適な分離法が望まれている。

これらの元案のイオン交換クロマトグラフィーとしては，酒石 酸を溶偝戍に用いて陽イオン交換樹脂によりスズとアンチモンを 分離する方法10〉むあるが，多くは陰イオン交換法で分離されてお り，とりわけ，塩素錯イオンの陰イオン交換吸着を利用する方法 が多く, 相互分離の研究としては, アンチモンーテルルースズは,

*1 Kazuaki KAWABUCHI 愛媛大学教育学部化学教室, 松 山市交京町

1) H. Hamaguchi, K. Kawabuchi, R. Kuroda, Anal., Chem., 36, 1654(1964).

2) 河洲, 分析化学, 14, 52(1965).

3) M. Fransworth, J. Pekola, Anal. Chem., 26, 735 (1954).

4) H. Onishi, E. B. Sandell, Anal. Chim. Acta, 14, 153 (1956).

5) C. L. Luke, Anal. Chem., 28, 1276(1956).

6) 石橋, 電松, 山本, 井上, 分析化学, 7, 473(1958).

7) 田中, 森川1!, 分析化学, 10, 396(1961).

8) 清水, 尾方, 分析化学, 12, 526(1963).

9) W. E. Nervik, NAS-NS 3023, "The Radiochemistry of Tin," U. S. Atomic Energy Commission(1960)p. 25.

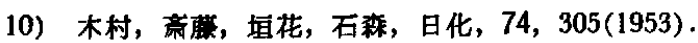

11) Y. Sasaki, Bull. Chem. Soc. Japan, 28, 615(1955).
インジウム, アンチモンーテルルースズ12)，七素ースズーアンチモ ン13)，鉛-銅-スズーアンチモン16などの 分離結果が 報告されてい る。このほか，七紊，スズ，アンチモンの硫化物を多酼化ナトリ ウムで処理して得られるチオ酸イオンを $\mathrm{OH}$ 形陰イオン交換樹脂 に交換吸着させ，水酸化カリウム溶液で分別溶離する 方法も提 出15)されている。

本法では，チオシアン酸形陰イオン交換樹脂を用いて，塩酸溶 液から，アンチモン(I)，スズ(IV)，モリブデン(隹)を樹脂に捕 捉させたのち，硫酸，塩化ナトリウム一水酸化ナトリゥム溶液を 溶離戍に用いてこれらの金属元素の相互分蜼法について険討し， よい結果を得たので報告する。

\section{2 实湥}

\section{1 试 萝}

イオン交換澍脂：Dowex 1 X-8(100〜200メッシュ)，水に1 夜浸して膨潤した塭素形陰イオン交換樹脂䄪 $100 \mathrm{ml}$ に希塩酸(蒸 留壏酸 1 : 水 4)1 $l$ を流す。垭素イオンを検出しなくなるまで水 洗後, $1 \mathrm{~mol} / l$ チオシアン酸アンモニウム溶液 $1 l$ を通して樹 脂をチオシアン酸形に変え, 水 $1 l$ で洗浄後吸引して水分を除 き，デシヶータ中の飽和真化カリウム上で保存する。

モリブデン原㭽：三酸化モリブデン $3.75 \mathrm{~g}$ を $1: 1$ アンモニ ア水 $10 \mathrm{ml}$ に溶解し, 塭酸で中和後, 塩酸泷度が $0.1 \mathrm{~mol} / l$ と なるように塩酸を追加し水で $50 \mathrm{ml}$ に希釈する。 オキシム法16)で標定した結果，この原液は Mo $49.0 \mathrm{mg} / \mathrm{ml}$ で あった。使用時は希釈して用いた。

スス原液：程化スズ(I)の $1.902 \mathrm{~g}$ 它 $6 \mathrm{~N}$ 塩酸 $17 \mathrm{ml}$ に溶解

12) I. Stroński, Chem. Abst., 55, 7096 h(196I).

13) M. N. Zvereva, E. A. Domitrieva, ibid., 55, 11184b (1961).

14) M. Ariel, E. Kirowa, Talanta, 8, 214(1961).

15) R. Klement, A. Kühn, Z. Anal. Chem., 152, 146 (1956).

16) W. F. Hillebrand, "Applied Inorganic Analysis 2nd Ed.", John Wiley \& Sons, Inc., New York(1955)p. 310. 
し， $30 \%$ 過酸化水素水 $1.5 \mathrm{ml}$ を加えてスズを酸化後，募漂して 過剩の過酸化水素を除き水で $100 \mathrm{ml}$ に希釈する。重量法17で摽 定した結果この原液は $\mathrm{Sn} 9.95 \mathrm{mg} / \mathrm{m} l$ であった。使用時は原液 または1N 增酸で遍当に希釈して用いた。

アンチモン原液：塩化アンチモン(II) $0.938 \mathrm{~g}$ を $6 \mathrm{~N}$ 程酸 50 $\mathrm{m} l$ に溶解し，水で $100 \mathrm{~m} l$ に希积した。容量法(19)で標定した結 果この原液は Sb $5.00 \mathrm{mg} / \mathrm{ml}$ であった。使用時は原液または 3N 塩酸で希釈して用いた。

ジチオール浚液: British Drug Houses 社製ジチオール(トルエ ン-3,4-ジチオール)を $0.25 \mathrm{~N}$ 水酸化ナトリウムに数滴のチオグ リコール酸とともに溶解し $0.1 \%$ 溶液を調製した。この溶液は長 期の保存ができないので使用の都度新しく調製した。

浴䧿液：硫酸は $2.5 \mathrm{~N}$, 水酸化ナトリウムは $2 \mathrm{~N}$, 塩化ナトリ ウムは $1 \mathrm{~mol} / l$ 溶液を調製して原液とし, 使用時は適当に希釈 して用いた。

その他：金属イオンの定量に必要な試薬は特級品をそのまま使 用し，水は眖イオン水を用いた。

\section{2 装}

イオン交換カラム: 断面積 $0.5 \mathrm{~cm}^{2}$, 長さ $20 \mathrm{~cm}$ の外筒付クロ マト用ガラス管に樹脂 $3.000 \mathrm{~g}$ を水でうるおして流しこみ, 器壁 についた樹脂は水でよく洗いおとす。樹脂が沈着したら水の流出 寸るのをまち， $1 \mathrm{~N}$ 硫酸 $30 \mathrm{ml}$ を流して樹脂をなじませる。外筒 には，はじめから恒温水を通してカラムを $25^{\circ} \mathrm{C}$ に保温する。

その他: 吸光度の貺定には日立製 FPW-4 型光䉓光度計を使用 し，吸収セルは光路長 $10 \mathrm{~mm}$ のものを用いた。必要により東洋 沪紙社製フラクションコレクターを使用したが，この場合フラク ションは比重より体穑に換算して捕集した。

\section{3 金属イオンの定旦法}

アンチモンはヨードアスコルビン酸法19), スズ4, モりブデン19) はジチオール法により定量した。スズの定量特, スズーシチオー ル錯体の分散绪には 0.5\% アラビヤゴム溶液を使用した。

\section{4 分布保数およびオ布比の測定}

分布係数 $\left(K_{d}\right)$ はバッチ法りまたはカラム法20)で測定した。バッ チ法では, 容量 $100 \mathrm{~m} l$ の共セン付三角フラスコに樹脂約 $1 \mathrm{~g}$ を

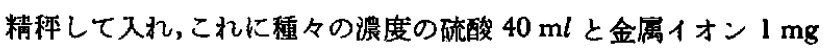
を含む $3 \mathrm{~N}$ 塩酸溶液 $1 \mathrm{ml}$ を加えて密センし, 室温で 6 時間ふり まぜたのち，口過して樹脂相と液相にわけ，液相の一定量を分取 して金属イオンを定量し, 式 (1)により分布係数 $\left(K_{d}\right)$ を算出し た。

$$
\begin{aligned}
& K_{d}(\mathrm{ml} / \mathrm{g}) \\
& \text { 樹脂相の金属イオン源度・液相の体樌 }(\mathrm{m} l) \\
& \text { 液相の金属イオン濃度・樹脂の重さ }(\mathrm{g})
\end{aligned}
$$

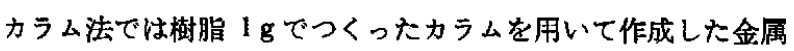

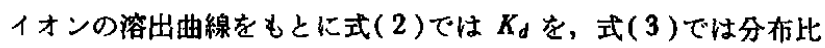

17) W. F. Hillebrand, "Applied Inorganic Analysis 2nd. Ed.", John Wiley \& Sons, Inc., New York(1955)p. 294.

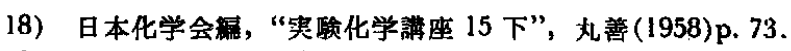

19) E. B. Sandell, "Colorimetric Metal Analysis 3rd Ed.", Interscience Publishers, Inc., New York(1959)p. 266, 650.

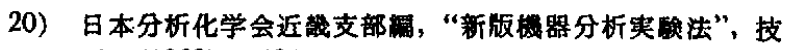
研社(1962)p. 425 .

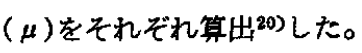

$$
\begin{aligned}
& V_{\mathrm{R}}=V_{l}+M \cdot K_{d} \\
& V_{\mathrm{R}}=V_{l}(1+\mu)
\end{aligned}
$$

式(2)，(3)で $V_{\mathrm{R}}$ : 金属イオンの保持容量 $(\mathrm{ml}), V_{l}:$ カ カムの 間げき液量, $M:$ 樹脂の重さ $(\mathrm{g})$ である。

\section{5 アンチモン, スズ, モリブデンの分椋}

2.2 で用意したカラムに, アンチモン(I), スス(N), モリフ デン( を $60 \mathrm{ml}$ 流入してアンチモンを溶出する。 ついで溶離液を 0.5 $\mathrm{mol} / l$ 塩化ナトリゥム $-0.5 \mathrm{~mol} / l$ 水酸化ナトリウム溶液にき りかえ, はじめの $6 \mathrm{~m} l$ はすて,つぎの $6 \mathrm{ml}$ を捕集してススの 定量を行ない,つぎの $6 \mathrm{ml}$ む捕集してモリブデンの定量を行な

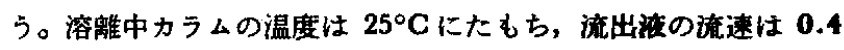
$\sim 0.5 \mathrm{ml} / \mathrm{min}$ とした。

\section{3 结果と考家}

\section{1 分布保数}

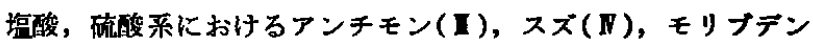
(1I)の分布係数をバッチ法で測定した結果, 表1に示すように 3 N塩酸溶液からはどの金属イオンも樹脂に強く吸差される。䤃酸 浱度を変えて測定すると,アンチモンの $\boldsymbol{K}_{d}$ 值は硫酸の混入によ って急激に減少し，一方スズとモリブデンは硫磁の泿度によって 多少異なるが，いすれも高い $K_{d}$ 值を示した。これより，3N 塯 酸溶液から金属イオンを樹脂に吸着させ，硫硫を流すとアンチモ ンのみが溶出することが示唆される。表 1 のアンチモンの $\boldsymbol{X}_{d}$ 值 で( )中の数值は， $25^{\circ} \mathrm{C}$ で 6 時間ふりまぜたときの值で，温度 が高いと $K_{d}$ 值が低くなることを示す。

表 1 堭酸一硫酸系に㧊けるアンチモン(I)，スズ(N)， モリブデン(U)の分布係数(室温: $13^{\circ} \mathrm{C}$ )

酸洪度 $\left\{\begin{array}{llllllll}\text { 硫 } & \text { 酸(N) } & 0.00 & 0.025 & 0.05 & 0.25 & 1: 0 & 2.5 \\ \text { 塭 } & \text { 期 } & 3.70 & 0.07 & 0.07 & 0.07 & 0.07 & 0.07\end{array}\right.$

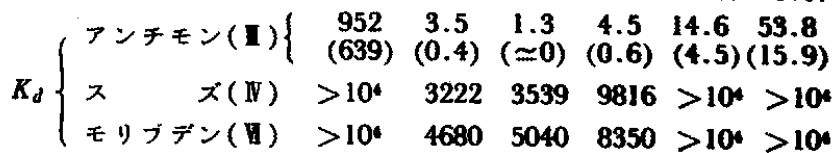

\section{2 硫酸によるアンチモンの济出}

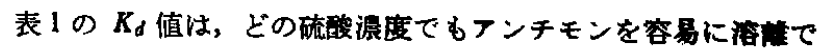
きることを示晙するので, 樹脂 $1 \mathrm{~g}$ でカラムをつくり, フンチモ

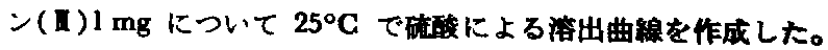

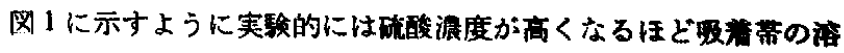
出は鋭敏になるが，どの硫酸搌度でもアンチモンは定量的に回取

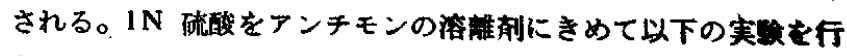
なった。

\section{3 スス，モリブデンの成出}

アンチモンの硫酸溶離獕中には、スズ，モリブデンはまったく

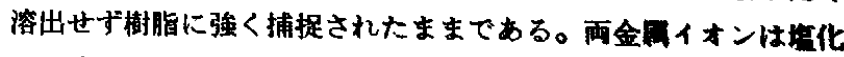

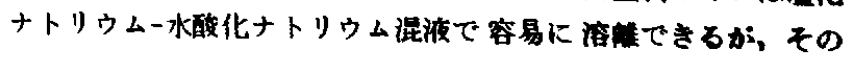
最道条件を梌討するため，樹脂 $1 \mathrm{~g}$ を用いてスズ，モりブデンに

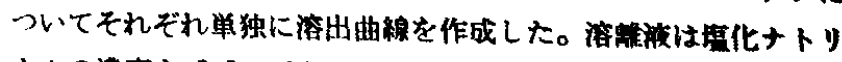

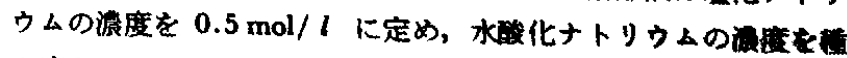
々変えた。四 2 の溶出曲線をもとに，式(2)により反山を界出し

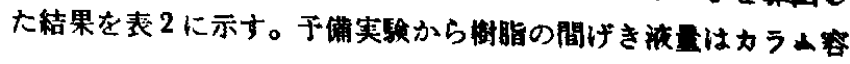




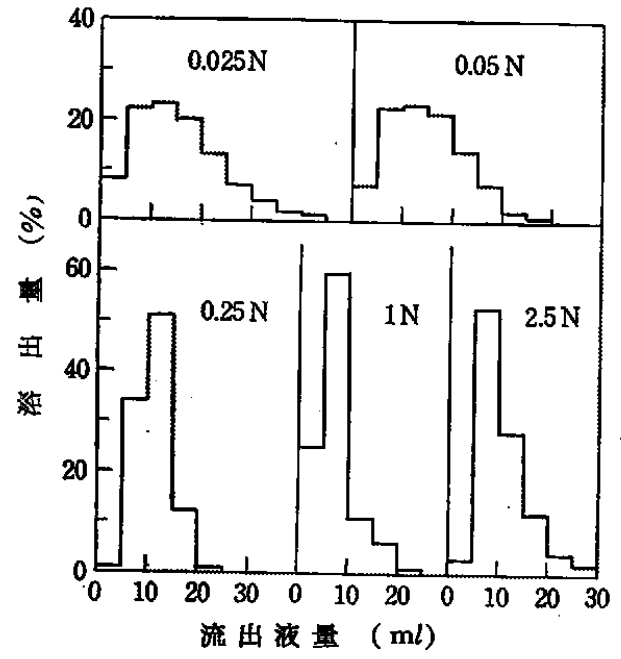

$\mathrm{Sb}$ (I) : $1 \mathrm{mg}$, カラム: $0.5 \mathrm{~cm}^{2} \times 4 \mathrm{~cm}$, 溶離液 : 硫酸

図1 アンチ.モンの溶出曲綄

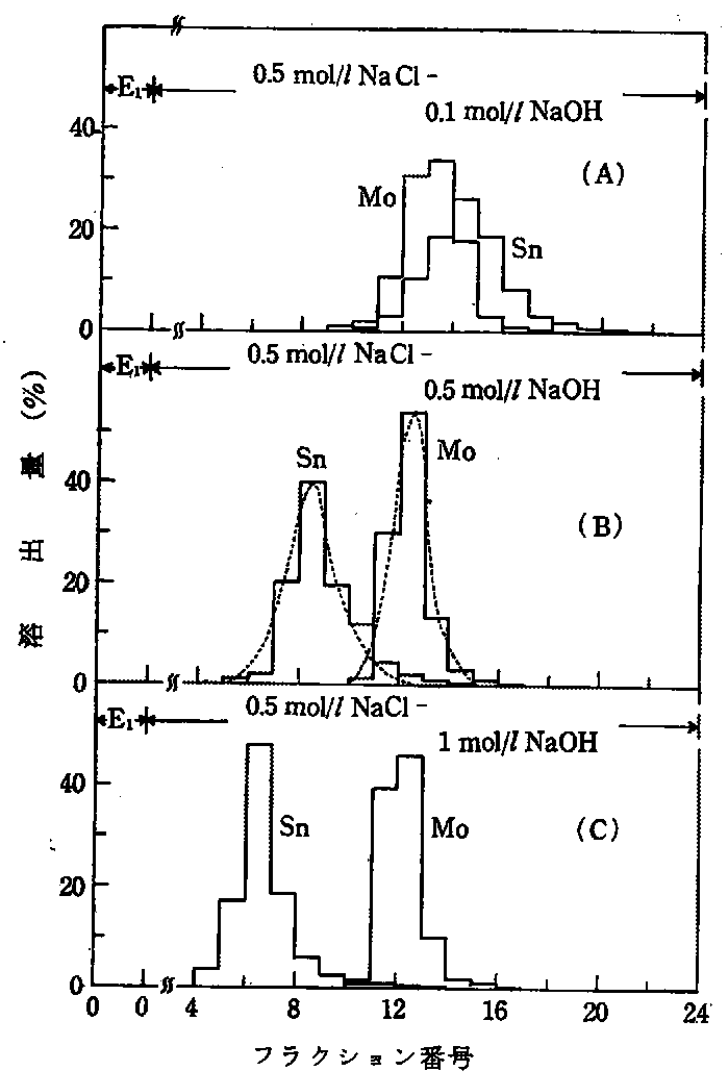

1 フラクション: 7/15 ml, Sn( IV) : $1 \mathrm{mg}, \mathrm{Mo}(\mathbb{I}): 1 \mathrm{mg}$, カラム: $0.5 \mathrm{~cm}^{2} \times 4 \mathrm{~cm}, E_{1}: 1 \mathrm{~N} \mathrm{H}_{2} \mathrm{SO}_{4} 30 \mathrm{ml}$

図 2 スズ，モリブデンの溶出曲線

表 2 塭化ナトリウム水酸化ナトリウム系化打ける スズ(V)，モりブデン(U)の分布係数(塩化ナ トリウム: $0.5 \mathrm{~mol} / l, 25^{\circ} \mathrm{C}$ )

\begin{tabular}{|c|c|c|c|}
\hline 化士卜 & 0.1 & 0.5 & 1.0 \\
\hline$\pi(\mathbb{V})$ & 6.13 & 3.32 & 2.39 \\
\hline モりブデン(苂) & 5.66 & 5.20 & 5.20 \\
\hline
\end{tabular}

垔 $\left(0.5 \mathrm{~cm}^{2} \times 4 \mathrm{~cm}\right) の 32 \%$ となり，これから $V_{l}=0.64 \mathrm{ml}$ とし て尌算した。

表示のよらに，モリブデンの $K_{d}$ 值は水酸化ナトリウムの濃厐
によって影䡒されずほほ一定であるが，スズの $K_{d}$ 值は水酸化ナ トリウムの浱度が高くなるほど低くなる。 $0.1 \mathrm{~mol} / l$ 水酸化ナト リウムではスズとモリブデンの $K_{d}$ 值はほとんど同じになるので 両者の分離のためには $0.5 \mathrm{~mol} / l$ または $1.0 \mathrm{~mol} / l$ 水酸化ナ トリウムを使用するのが適当である。

\section{4 イオン交換カラムのサイズ}

図 2 の溶出曲線から，1g の樹脂でっくったカラムではスズと モリブデンに相互污染がみられ満足な分離ができないことが予想 される。溶出曲線の形状から，溶離液を $0.5 \mathrm{~mol} / l$ 塩化ナトリ ウム $-0.5 \mathrm{~mol} / l$ 水酸化ナトリウム溶液にきぬ, 因 2 (B)から点 線で示すような溶出曲線を仮定して Beukenkamp ら 21 222) の式に より，この溶離系でスズとモリブデンを分離するのに必要なカラ ムの商さを算出した。

図 2 (B)の作成に使用したカラムの容量は $0.5 \times 4 \mathrm{~cm}^{3}$, 間げき 液量は $0.64 \mathrm{ml}$ ，スズとモリブデンの保持容量はそれぞれ 3.96, $5.84 \mathrm{ml}$ である。これからら分布比 $(\mu)$ は, 式(3)加ら $\mu_{\mathrm{Sn}}=5.2$, $\mu_{\mathrm{Mo}}=8.1$ となり, 理論段数 $(r)$ はそれぞれ $r_{\mathrm{Sn}}=71.0, r_{\mathrm{Mo}}=$ 188.7 となる。したがって $1 \mathrm{~cm}$ あたりの段数 $(R)$ は $R_{\mathrm{Sn}}=17.7$ ， $R_{\mathrm{Mo}}=47.2$ となり，こ私からスズとモリブデンを分離するのに 必要なカラムの高さは近似的に $8.7 \mathrm{~cm}$ となる。

溶出曲線にみられるように，この溶離系ではスズはいくぶんテ イリングを示すので,カラムの高さは計算值より多少余裕をみて， 実際には $12 \mathrm{~cm}$ のカラムになるように樹脂 $3 \mathrm{~g}$ を使用した。ア

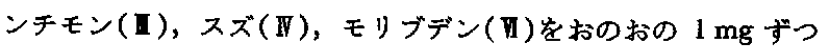
含を試料溶液について, $12 \mathrm{~cm}$ のカラムを用いて溶離実験を行な った結果，図 3 に示すように三者を分離できた。

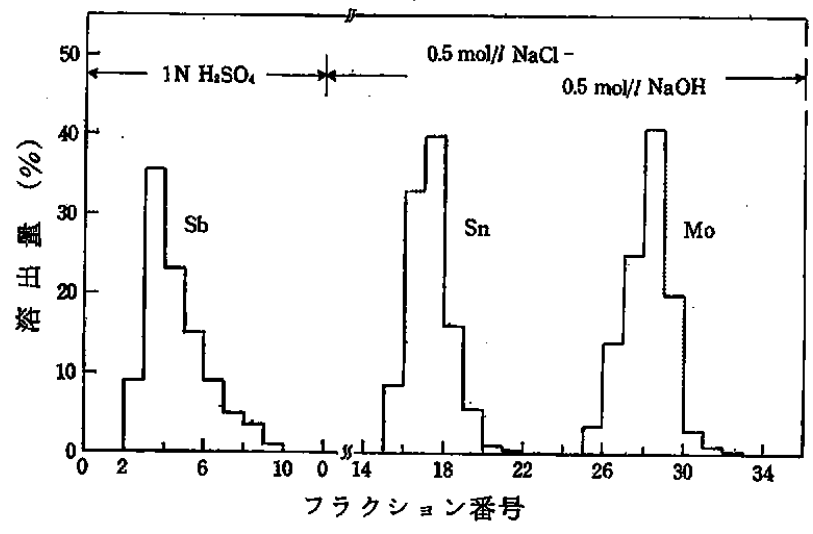

$\mathrm{Sb}$ (I) : $1 \mathrm{mg}, \mathrm{Sn}(\mathbb{V}): 1 \mathrm{mg}, \mathrm{Mo}(\mathrm{V}): 1 \mathrm{mg}$ カラム: $0.5 \mathrm{~cm}^{2} \times 12 \mathrm{~cm}$, 温度: $25^{\circ} \mathrm{G}$,

流速 : $0.5 \mathrm{ml} / \mathrm{min}, 1$ フラクション: $\mathrm{Sb}, 5 \mathrm{ml}$, $\mathrm{Sn}, \mathrm{Mo}, 7 / 15 \mathrm{ml}$

図 3 アンチモン，スズ，モリブデンの分睢

\section{5 アンチモン，スズ，モリブデンの分離と回収}

各金属元素の原液から，種々の割合に金属イオンを含む試料溶 液を調製して， $0.5 \mathrm{~cm}^{2} \times 12 \mathrm{~cm}$ のカラムで 各元素を 分離した。 溶出曲線の一例を図4に示すが，スズおよびモリブデンの溶出の 状況は金属イオンの量に関係なくほとルど一定である。表 3 に分

21）日本分析化学会近戴支部編，“新版機興分析実䙴法”, 技研社 (1962)p. 426.

22) J. Beukenkamp, W. Rieman III, S. Lindenbaum, Anal. Chem., 26, 505(1954). 


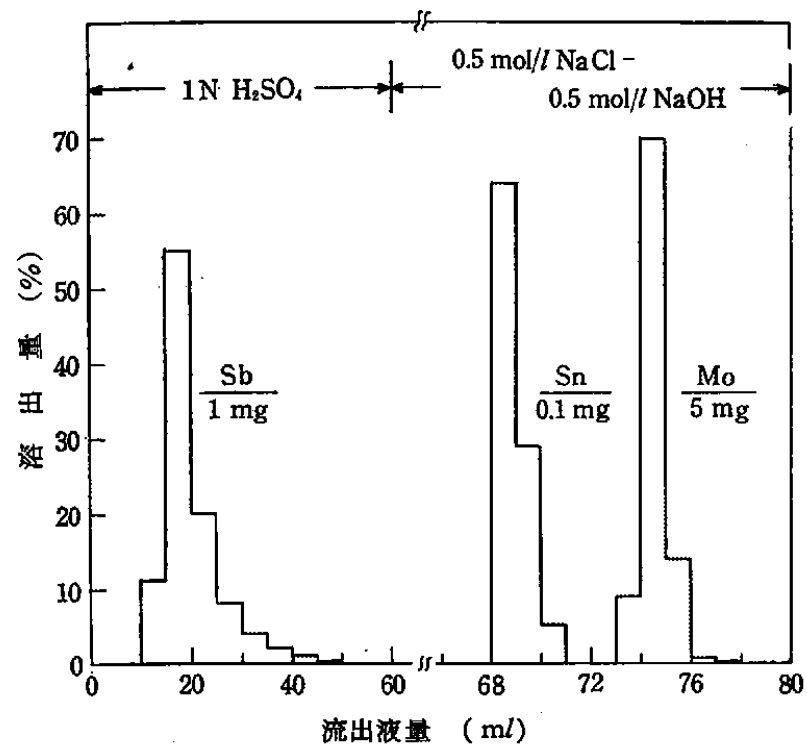

図 4 アンチモン，スズ，モリブデンの分㪀

表 3 アンチモン，スズ，モリブデンの分離と回取

\begin{tabular}{|c|c|c|c|c|c|c|}
\hline \multirow{2}{*}{$\begin{array}{l}\text { 実験 } \\
\text { 番号 }\end{array}$} & \multicolumn{3}{|c|}{ 添如量(mg) } & \multicolumn{3}{|c|}{ 回収量(mg) } \\
\hline & $\mathrm{Sb}(\mathrm{I})$ & $\operatorname{Sn}(\mathbb{I})$ & $\operatorname{Mo}(\mathrm{V})$ & $\mathrm{Sb}$ & $\mathrm{Sn}$ & Mo \\
\hline 1 & 1.00 & 1.00 & 0.98 & 1.02 & 1.00 & 0.99 \\
\hline 2 & 1.00 & 1.00 & 0.98 & 1.04 & 0.99 & 0.97 \\
\hline 3 & 1.00 & 4.98 & 0.20 & 0.51 & 5.00 & 0.20 \\
\hline 4 & 1.00 & 4.98 & 0.20 & 0.50 & 5.08 & 0.21 \\
\hline 5 & 1.00 & 4.98 & 0.20 & 0.41 & 4.95 & 0.20 \\
\hline 6 & 0.20 & 1.00 & 0.10 & 0.13 & 0.99 & 0.10 \\
\hline 7 & 1.00 & 0.10 & 4.90 & 1.01 & 0.10 & 4.71 \\
\hline 8 & 1.00 & 0.10 & 4.90 & 1.03 & 0.10 & 4.81 \\
\hline 9 & 5.00 & 0.02 & 0.02 & 5.07 & 0.02 & 0.02 \\
\hline
\end{tabular}

離と回収の結果を示す。

表示のようにスズとモりブデンの回収量は共存する金属イオン の量や吸着させた量に関係なく完全であるが，共存するスズの量 がアンチモンに対して多い場合はアンチモンの溶出が不完全とな る。試料浴液中のスズとアンチモンの存在比とアンチモンの回収 の関係を，樹脂 $1 \mathrm{~g}$ でつくったカラムを用いて 検討した結果， 表 4 に示す.ようにスズとアンチモンの重量比が 2 以上になると 1 N砝酸で回収できるアンチモンの量は不完全となる。現在のとこ ろこの理由は明らかでない。

表 4 共存するスズの量とアンチモンの回収率

\begin{tabular}{|c|c|c|c|c|c|}
\hline \multirow{2}{*}{$\begin{array}{l}\text { 実験 } \\
\text { 番费 }\end{array}$} & \multicolumn{2}{|c|}{ 添加量(mg) } & \multirow{2}{*}{$\mathrm{Sn} / \mathrm{Sb}$} & \multicolumn{2}{|c|}{ 回収量 } \\
\hline & $\operatorname{Sn}(I)$ & $\mathrm{Sb}(\mathrm{I})$ & & $\mathrm{Sb}$ (mg) & $\mathrm{Sb}(\%)$ \\
\hline 1 & 0.50 & 0.50 & 1 & $0.50_{1}$ & 102.0 \\
\hline 2 & 1.00 & 0.50 & 2 & $0.49_{8}$ & 99.6 \\
\hline 3 & 2.00 & 0.50 & 4 & $0.38_{7}$ & 77.4 \\
\hline 4 & 3.00 & 0.50 & 6 & 0.250 & 50.0 \\
\hline 5 & 4.00 & 0.50 & 8 & $0.27_{0}$ & 54.0 \\
\hline 6 & 5.00 & 0.50 & 10 & $0.32_{5}$ & 65.0 \\
\hline 7 & 6.00 & 0.50 & 12 & 0.255 & 51.0 \\
\hline
\end{tabular}

終りに，原稿の校閲と御批判を赐わった千莱大学工学部黑田六 郎教授飞感謝の意を表します。

（1965 年 11 月；日本分析化学会第 14 年会鿁演）

\section{ヒラミレモンの葉の 粮油成分 \\ （跖和 40 年 7 月 19 日受理）}

$$
\text { 外間宏 三*1 }
$$

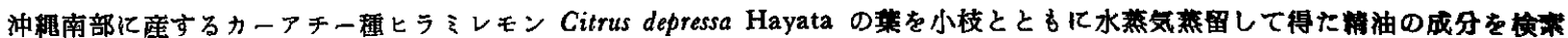

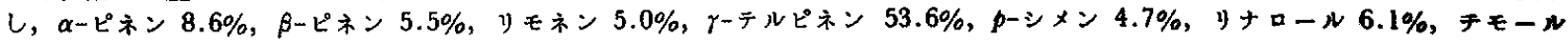
メチルエーエル 8.1\% 和よびその他 11 成分 $8.4 \%$ からなるととを明らかとした。

\section{1 緒 言}

ヒラミレモン Citrus depressa Hayata は蝇地方に産し,こ の地方では“シイイクワーシャー(Shiikwaska)” と眯ばれ，その 呼称が和名となっている。このシイイクワーシャーと㭔ばれるも のには, カーアチー種, カービシー種烙など二, 三の品種がある

*1 Kozo HoKAMA 琉球大学文理学部化学教室, 沖稆那䣓 市

*2 カーアチーとは実の皮が厚い，カービシーとは実の皮が うすいという意.
が、田中1はこれらはいずれもシイイクワーシャーであるとして いる。

ヒラミレモンの精油成分に图しては現在まで却告がない。そこ で今回カーアチー種ヒラミレモンの葉の精油成分を検索した。

\section{2 蛣果およひ考察}

固定相液体 PEG 6000 , カラム温度 $130^{\circ} \mathrm{C}, \mathrm{H}_{2}$ ガス $65 \mathrm{ml} /$ $\min$ の条件下における精油のガスクロマトグラムは四1のようで

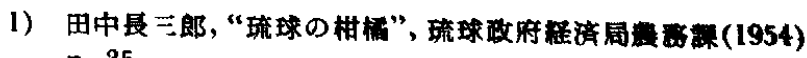
p. 35 . 